\title{
A conserved enhancer of the human and murine Hoxa-7 gene specifies the anterior boundary of expression during embryonal development
}

\author{
Thomas Knittel, Michael Kessel, Myoung Hee Kim and Peter Gruss* \\ Abteilung für molekulare Zellbiologie, Max Planck Institut für biophysikalische Chemie, Am Fassberg, 37077 Göttingen, Germany \\ ${ }^{*}$ Author for correspondence
}

\section{SUMMARY}

The murine homeobox-containing gene $\mathrm{Hoxa}-7$ is expressed in restricted patterns during embryogenesis and plays an important role in the control of region-specific differentiation. Previous studies have shown that separate elements specify lineage restriction and expression boundaries of Hoxa-7. In particular $3.6 \mathrm{~kb}$ of $5^{\prime}$ flanking sequences were sufficient to establish an anterior boundary of Hoxa-7 gene expression. To identify the minimal regulatory element specifying the anterior boundary of expression, transgenic mice were generated carrying chimeric constructs with deletions of 5 ' flanking sequences fused to a thymidine kinase minimal promoter/E. coli lac Z reporter construct. By deletion analysis, a 470 bp long control element (AX 470) located $1.6 \mathrm{~kb}$ upstream of the transcription start site was identified that directed expression of the $\beta$-galactosidase protein in a pattern reflecting the anterior boundary of expression of the endogenous Hoxa-7 gene. This element was active in either orientation and conferred regionspecific expression to unrelated promoters, thereby behaving like an enhancer element. In contrast, transgenic mice carrying further $5^{\prime}$ and $3^{\prime}$ deletions of the $470 \mathrm{bp}$ long element did not exhibit an anterior boundary of Hoxa-7 expression. Based on these results the minimal control element (AX 470) specifying the anterior boundary of Hox expression was designated as Hoxa-7 enhancer.

Furthermore, $3 \mathrm{~kb}$ of the human $\mathrm{HOXA7}$ upstream region were sequenced and compared to its mouse homologue in order to identify conserved regions. Sequence comparison revealed motifs that were strongly conserved between both species. The human homologue of the mouse Hoxa-7 enhancer was $70 \%$ identical at the nucleotide level and was also capable of directing an anterior boundary in transgenic mice.

Using transgenic lines a detailed analysis of the Hoxa-7 enhancer-directed expression during embryogenesis was performed. lac $Z$ expression was first detected in the allantois at day 7.5 p.c. and in mesoderm and ectoderm at day 8.5 of gestation. Between gestational ages E8.5 to E12.5 $\beta$-gal expression was observed in the somites, spinal cord, spinal ganglia and paraxial mesoderm as well as in mesenchymal layers of the kidney. A distinct anterior limit of expression was noted in transgenic lines at level C4 (neural tube) and C5 (spinal ganglia).

Our deletion experiments defined a minimal enhancer element specifying the anterior boundary of Hox gene expression in early and late phases of development. Further studies aim at characterizing the trans-acting factors that mediate the spatial and temporal expression of Hox genes in the developing embryo.

Key words: Hoxa-7, enhancer, anterior expression boundary, transgenic mice, lacZ, HOXA7

\section{INTRODUCTION}

Homeobox-containing genes encode DNA-binding proteins, which are highly conserved throughout evolution and function as transcriptional regulators. Homeotic genes were first identified in Drosophila melanogaster and a causal linkage between the expression of these genes and the identity of segmental units has been established (Akam et al., 1988). In higher vertebrates the 38 Hox genes correspond both functionally and structurally to the homeotic genes of Drosophila. They are organised in four separate gene clusters and are assumed to have arisen by duplication and expansion of an ancestral complex (Kappa et al., 1993; Schubert et al., 1993). Hox genes are expressed in mesoderm and neuroectoderm in non- identical, overlapping domains (Kessel and Gruss, 1990; McGinnis and Krumlauf, 1992). The distinct combination of expressed Hox genes in segments along an anterior-posterior axis was defined as the Hox code (Hunt et al., 1991; Kessel and Gruss, 1991). The functional significance of the Hox code in the specification of positional identities during development in vertebrates was established by ectopic expression of Hox genes (Balling et al., 1989; Kessel et al., 1990; Lufkin et al., 1992; Morgan et al., 1992), by the introduction of loss of function mutants (Chisaka and Capecchi, 1991; Chisaka et al., 1992; Lufkin et al., 1991), in vivo modulation of Hox genes by retinoic acid (Kessel, 1992, 1993; Kessel and Gruss, 1991) and transplantation experiments (Guthrie et al., 1992).

In invertebrates and in vertebrates there is a direct relation- 
ship between the position of a gene in the cluster and its time of activation during development. As a consequence, the anterior expression domains of genes at the $5^{\prime}$ end are localised more caudally whereas those of the $3^{\prime}$ genes are more rostral. Alterations of the exact settings of anterior boundaries using ectopic expression, retinoic acid exposure or inactivation of Hox genes causes homeotic transformations to more anterior or posterior structures depending on the experimental system. Therefore identification of regulatory elements controlling the activity of homeotic genes, especially regulators defining the onset of expression in time and space, is of crucial importance for the understanding of the developmental program specifying positional information e.g. along the anteroposterior axis of the vertebrate embryo. Experiments using transgenic animals have demonstrated that the normal, endogenous expression pattern of a Hox gene can be completely or partially recapitulated by placing genomic DNA fragments outside of the Hox complex. Both general and tissue-specific regulatory elements were identified in homeobox genes: Hoxa-4 (Behringer et al., 1993), Hoxa-5 (Tuggle et al., 1990; Zakany et al., 1988), Hoxa-7 (Püschel et al., 1990, 1991, 1992), Hoxb1 (Marshall et al., 1994; Studer et al., 1994), Hoxb-4 (Whiting et al., 1991), Hoxb-6 (Schughart et al., 1991), Hoxb-7 (Kress et al., 1990; Vogels et al., 1993), HOXC6 (Jegalian et al., 1992), Hoxc-8 (Bieberich et al., 1990) and Hoxd-11 (Gerard et al., 1993). Although the complete temporal and spatial pattern of Hox gene expression was regained in only a few cases using lacZ reporter constructs (Behringer et al., 1993; Püschel et al., 1991; Whiting et al., 1991) the detailed analysis of Hox promoter sequences in transgenic mice identified DNA regions controlling different aspects of Hox gene expression, e.g. limits of expression boundaries and tissue restriction. Based on these results and observations made in Drosophila there is growing evidence that Hox gene regulation along an anterior-posterior axis involves the interaction of a series of distinct elements. Definition of these elements is expected to lead to the identification of interactions either in cis, or in trans, involved in the regulatory process. So far Hox sequences with regulatory potential are rather large and information about precisely defined regulatory units is limited. With the exception of the interaction between Krox-20 and HOXB2 during hindbrain segmentation as well as the role of retinoic acid in establishing the segment restricted expression of Hoxb-1, no definite correlation between transcription factors and target sequences has been made (Marshall et al., 1994; Sham et al., 1993; Studer et al., 1994). However, mapping of distinct regulatory units is an essential step in understanding the functional organisation of the Hox complex and expression of the lacZ gene under the control of Hox genomic sequences in vivo represents a valid approach for the identification of cis-acting elements.

The aim of the present study was the identification of the minimal control element specifying the anterior boundary of Hoxa-7 expression in time and space. During development, expression of the endogenous Hoxa-7 gene is detectable during gastrulation, initially in the allantois (7.5 days p.c.) and subsequently in specific regions of the neuroectoderm and mesoderm (Mahon et al., 1988). During organogenesis Hoxa-7 is restricted to successively smaller sets of cells and specific transcripts are present in distinct overlapping region- and stage-specific patterns (Dressler and Gruss, 1989; Kessel and Gruss, 1991; Mahon et al., 1988). At day 12.5 p.c. Hoxa-7 is expressed in the neural tube and spinal ganglia from $\mathrm{C} 4$ to $\mathrm{S} 4$, the prevertebrae from T3 to T13 and in the developing kidney and stomach. Previous studies have shown that $3.6 \mathrm{~kb}$ of $5^{\prime}$ and $1.7 \mathrm{~kb}$ of $3^{\prime}$ sequences provide sufficient regulatory information to express a transgene in a spatial and temporal manner indistinguishable from the endogenous Hoxa-7 gene during the period of development when Hoxa-7 expression is established (Püschel et al., 1990). Furthermore, at least three distinct elements responsible for different levels of control, being active at different stages of development, were identified (Püschel et al., 1991). $3.6 \mathrm{~kb}$ of 5 ' sequences, element A, specifies the anterior boundary of Hoxa-7 expression in ectoderm and mesoderm. Element B, a $130 \mathrm{bp}$ non-translated leader sequence, was shown to be crucial for (i) setting the posterior boundary in mesoderm and ectoderm derived structures, (ii) restricting expression to the ventral half of the neural tube and (iii) mediating lineage restriction to sclerotomal cells. Element $\mathrm{C}$, compromising the intron and parts of the first and second exon, was necessary to confine expression to prevertebrae.

In the present study deletion analysis, starting from a previously described Hoxa-7/lacZ transgene, identified a minimal regulatory element located $1.6 \mathrm{~kb}$ upstream of the transcripion start site. This control element specified the anterior boundary of Hoxa-7 expression in early and late phases of development. The element was active in either orientation and conferred region-specific expression to unrelated promoters thereby behaving like an enhancer. Furthermore, structure and function of the Hoxa-7 enhancer was highly conserved between human and mouse.

\section{MATERIAL AND METHODS}

\section{Sequencing the human HOXA7 upstream region}

Standard recombinant DNA procedures were followed according to the method of Maniatis (Maniatis et al., 1982). Clone cD9 containing the human HOXA7 upstream region was a kind gift from Edoardo Boncinelli (Milan, Italy). A $3.6 \mathrm{~kb}$ SalI-SacI fragment of clone cD9 was cloned into Bluescript $\mathrm{KSII}^{+}$and analysed by restriction digestion. Appropriate fragments ranging from $200 \mathrm{bp}$ to $500 \mathrm{bp}$ in size were subcloned into Bluescript $\mathrm{KSII}^{+}$and sequenced in both directions by use of the chain termination method and automatated sequencing. Sequence comparison showed that the $3.6 \mathrm{~kb}$ SalI-SacI fragment contained $0.6 \mathrm{~kb}$ vector sequences at the $5^{\prime}$ end and $3.0 \mathrm{~kb}$ HOXA7 genomic DNA.

\section{Construction of hybrid genes}

For deletion analysis of the Hoxa-7 promoter, a reporter construct containing a herpes simplex thymidine kinase (Tk) minimal promoter, the bacterial lacZ gene and a SV40 polyadenylation site was constructed by linking the following fragments in the indicated order: a $1.38 \mathrm{~kb}$ Bam HI-ClaI fragment carrying the Tk minimal promoter and a portion of the bacterial lacZ gene from pB-TKlacZ (Scholer et al., 1989), a $1.7 \mathrm{~kb}$ ClaI-NaeI fragment from pZ1SVpA and a BamHINaeI fragment from m6lacZ1A (Püschel et al., 1991). pZ1SVpA was generated by cloning a 470 bp KpnI-EcoRI fragment carrying the SV40 polyadenylation site into the KpnI-EcoRI site of pB-TKlacZ (Scholer et al., 1989) creating a SnabI site by recutting at the KpnI site, end-filling with Klenow and blunt end ligation. A HindIII-BamHI fragment was separated from the reporter construct to remove Hoxa7 upstream regions derived from m6lacZ1A and these unique HindIII and BamHI sites were used to clone a series of Hoxa-7 upstream fragments in front of the Tk minimal promoter. 
Different Hoxa-7 upstream fragments were amplified using PCR. For PCR, m6lacZ1A (Püschel et al., 1991) was used as template DNA and 18 mer sense and antisense primers carrying additional HindIII or $B g I I I$ cloning sites were used, respectively. PCR was performed under standard conditions using Taq polymerase. PCR products were digested with HindIII or BgllI, purified on agarose gels, electroeluted and cloned into the reporter vector. All constructs used in this study were sequenced to detect possible base changes due to the error rate of Taq DNA polymerase. Fig. 1 gives an overview of the constructs used to identify the minimal regulatory element specifying the anterior boundary of Hox gene expression. To clone AX 470 in reverse orientation sense primers carrying a $B g l I I$ site and antisense primers with an HindIII site were used. AX minus was generated by fill in reaction and blunt end cloning of the HindIII-BamHI digested reporter vector. To amplify the human homologue of mouse AX 470 a 502 bp long fragment was amplified from clone cD9.

The fusion gene was separated from the vector for injections by HindIII-SnabI digestion. Restriction fragments were separated on agarose gels and isolated by electroelution. The fragment of interest was further purified on agarose gels, electroeluted, purified by phenol chloroform extraction, followed by chloroform extraction, gel filtration over a Elutip column (Schleicher and Schuell) and passed through a 0.22 $\mu \mathrm{m}$ filter (Schleicher and Schuell).

\section{Generation of transgenic mice}

NMRI outbred mice and C57BI6/DBA-F1 were purchased from the Zentralinstitut für Versuchstierzucht (Hannover, Germany). Transgenic mice were produced according to the method of Hogan (Hogan et al., 1986). Briefly, 6 week old NMRI female mice were superovulated by intraperitoneal injection of 5 IU gonadotropin from pregnant mare serum 48 hours prior to injection of $5 \mathrm{IU}$ of human chorionic gonadotropin. Female mice were then mated with C57BI6/DBA-F 1 male mice. One day later 1 cell embryos were flushed from the oviducts with M2 medium (Hogan et al., 1986) and eggs were freed of cumulus cells by hyaluronidase treatment. The male pronuclei of fertilised eggs were microinjected with approximately 2 pL DNA at a concentration of $2 \mathrm{ng} / \mu \mathrm{l}$. Injected eggs were transferred to pseudopregnant recipient NMRI female mice.

Resulting pregnant females were either killed at day 12.5, after injection, for $\mathrm{F}_{0}$ embryo analysis, or allowed to bring foetuses to term for generation of transgenic lines. Transgenic embryos of $\mathrm{F}_{0}$ generation were identified by PCR of DNA purified from extraembryonic yolk sac. Transgenic mouse lines were generated by mating founder animals or $F_{1}$ mice with NMRI mice. Transgenic mice were identified by Southern blot analysis or PCR of DNA extracted from mouse tail biopsies as described by Hogan (Hogan et al., 1986). PCR was performed at $65^{\circ} \mathrm{C}$ annealing temperature for 35 cycles using lacZ-specific primers (sense primer: 5' CGGCTTCGTCTGGGACTGGGT 3', antisense primer: 5' CCAGGCGCTGATGTGCC CGGC 3'); for Southern blot analysis a lacZ-specific probe was used.

\section{X-Gal staining and histology}

Embryos between days 6.5-17.5 p.c. (day of vaginal plug or retransfer was designated as day 0.5) were dissected in PBS and were fixed in $1 \%$ formaldehyde, $0.2 \%$ glutaraldehyde, $0.02 \%$ NP40 in $1 \times$ PBS for 30 minutes at $4{ }^{\circ} \mathrm{C}$. Developmental stages of embryonic specimens was reconfirmed according to Theiler (Theiler, 1972). Embryos were washed three times in $1 \times$ PBS for 20 minutes each at room temperature. Embryos were stained in the dark at $30^{\circ} \mathrm{C}$ in $1 \mathrm{mg} / \mathrm{ml} \mathrm{X-Gal,} 5$ $\mathrm{mM} \mathrm{K} \mathrm{K}_{3} \mathrm{Fe}(\mathrm{CN})_{6}, 5 \mathrm{mM} \mathrm{K} 4 \mathrm{Fe}(\mathrm{CN})_{6}, 2 \mathrm{mM} \mathrm{MgCl}_{2}$ in $1 \times \mathrm{PBS}$ overnight and washed three times in $1 \times$ PBS for 20 minutes each at room temperature. For embryos between days 13.5 and 17.5, $1 \times$ PBS containing $0.01 \%$ sodium deoxycholate during washing and staining procedures was used and fixation was performed for 1 hour. Embryos

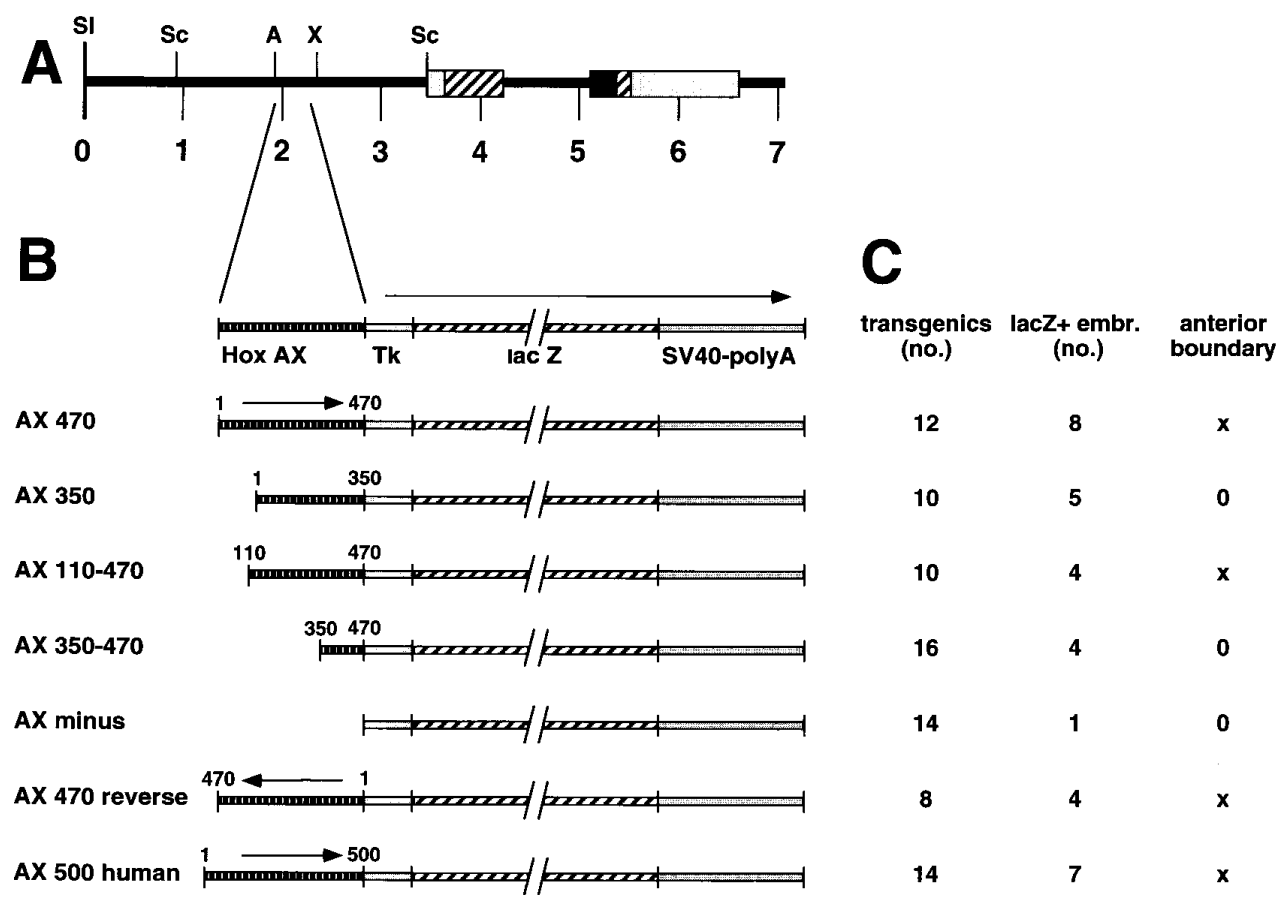

Fig. 1. Constructs used to identify a minimal cis-acting upstream element specifying the anterior boundary of Hoxa-7 expression. (A) Genomic organisation of the Hoxa-7 locus spanning $7.1 \mathrm{~kb}$. Boxes represent exons, hatched boxes indicate Hoxa-7 coding sequences, black boxes the homebox and stippled boxes $3^{\prime}$ and $5^{\prime}$ non translated sequences. Sizes are indicated in $\mathrm{kb}$. Abbreviations of restriction sites and positions according to Püschel (1990): Sl, SalI (position 0); Sc, SacI (position 861 and 3637); A, AluI (position 1944); X, XhoI (position 2616). (B) Schematic presentation of the constructs used to generate transgenic mice. In general, fragments located within the Hox upstream region between the Alu I and Xho I site (AX fragments) were generated using PCR and were placed in front of a Tk minimal promoter/E. coli lacZ/SV40-poly A reporter construct (see Material and Methods). The $470 \mathrm{bp}$ long fragment AX 470 spans from the AluI site (position 1944) to position 2414. $5^{\prime}$ and $3^{\prime}$ deletions of the $470 \mathrm{bp}$ long AX fragment are named according the construct length or to their position within the AX 470 fragment. In AX 470 reverse, AX 470 is cloned in the opposite direction in front of the reporter construct. AX human represents the human homologue of the mouse AX 470 fragment amplified by PCR from clone cD9 (see also Fig. 5 for complete AX 500 human sequence). Arrows indicate orientation. (C) Summary of transgenic embryos (transient assays). Total numbers of transgenic embryos identified by PCR (transgenics) carrying constructs AX 470, AX 350, AX 110-470, AX 350-470, AX minus, AX 470 reverse or AX 500 human are given. Furthermore, total numbers of lacZ-positive embryos (lacZ+embr.) and embryos showing an anterior boundary of expression (X, anterior boundary of expression; 0 , no anterior boundary of expression) are indicated (for further information see text and Table 1). 
were cleared in $30 \%, 50 \%$ and $80 \%$ glycerol sequentially, photographed as whole mounts and stored in the dark at $4^{\circ} \mathrm{C}$ until further analysis. For sectioning, stained embryos were equilibrated back into PBS, dehydrated and embedded in paraffin. Sections were cut (12 $\mu \mathrm{m})$, dewaxed and counterstained with neutral red. A consecutive numbering of the vertebrae and spinal ganglia (C1-C7, T1-T13) starting with the atlas $(\mathrm{C} 1)$ and the spinal ganglion located between atlas and axis (C2) was applied. The segmental level of expression in the neural tube was defined by adjactent vertebrae or spinal ganglia.

\section{RESULTS}

\section{Conservation of the Hoxa-7 upstream region between human and mouse}

Based on the assumption that potential regulatory regions within the Hoxa-7 promoter should be conserved through evolution, human and mouse Hoxa-7 upstream regions were sequenced and compared by general GCG alignment programs. $3.034 \mathrm{~kb}$ of human and $3.642 \mathrm{~kb}$ of mouse genomic sequences upstream of the common $\mathrm{SacI}$ site located within the first exon were analysed. The restriction map of the human and mouse Hoxa-7 upstream region and the homology at the nucleic acid level are illustrated in Fig. 2. Using the wordsearch program (word size 6, integral width 3) an average match of 0.38 between the entire mouse and human upstream region was noted. However, a more detailed analysis using the Fasta homology search program (word size 6) identified regions that were highly conserved between both species. Directly upstream of the SacI site (position 3516-3642) human and mouse upstream sequences were $88 \%$ identical at the nucleotide level, differing only in 15 positions over $126 \mathrm{bp}$. In
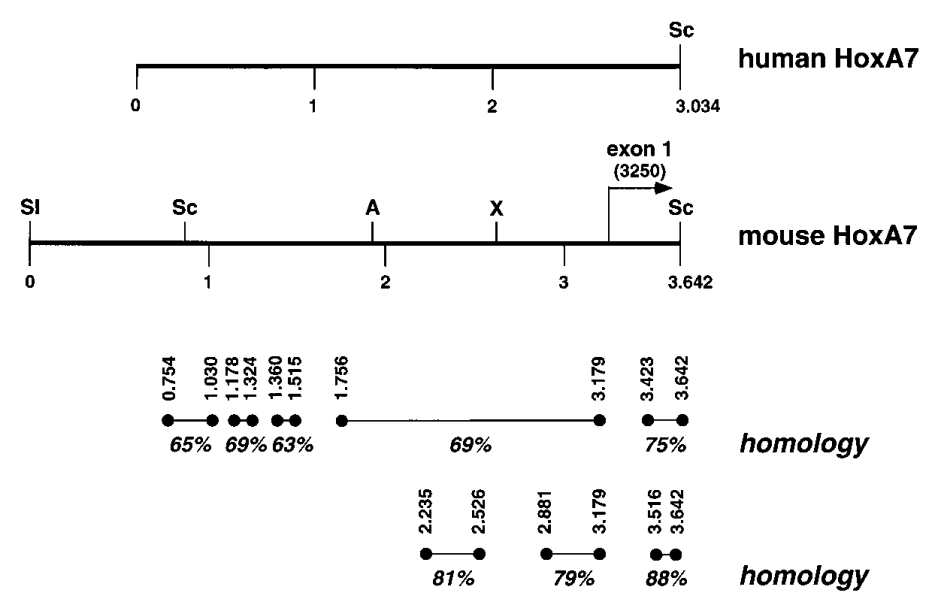

Fig. 2. Sequence homology of the human and mouse Hoxa-7 upstream region. Diagram showing the human and mouse genomic region upstream of a common Sac I site at $3.034 \mathrm{~kb}$ and $3.642 \mathrm{~kb}$, respectively. In the mouse genome this Sac I site is located within the first exon starting at $3.250 \mathrm{~kb}$. Sequence comparison was performed by Fasta or BestFit alignment programs using standard parameters. Upstream areas with a high degree of similarity are illustrated by solid lines and the percentage homology is indicated in italics. Positions correspond to the mouse Hoxa-7 promoter sequence. Abbreviations of restriction sites and positions according to Püschel et al. (1990): Sl, SalI (position 0); Sc, SacI (position 861 and 3637); A, AluI (position 1944); X, XhoI (position 2616). contrast, $5^{\prime}$ of position 3423 , extending to position 3179 , mouse and human upstream sequences diverged more than $50 \%$. The region spanning 1756- 3179 showed 69\% identity over 1423 bp totally and contained DNA elements with high similarity scores. One region spanning from 2235-2526 displayed $81 \%$ homology over 291 bp and a second region located at position 2881-3179 was 79\% identical over 297 bp. In addition, upstream of position 1756, 3 areas with similarity scores ranging between $63 \%$ and $69 \%$ were identified. In summary, these results support the hypothesis that human and mouse Hoxa-7 upstream regions are conserved throughout evolution and that those areas with a high degree of homology play a putative role in the regulation of Hoxa-7 gene expression.

\section{Identification of a minimal control element specifying the anterior boundary of Hoxa-7 expression}

Previous experiments have shown that a $1.6 \mathrm{~kb}$ nucleotide sequence located upstream of the Hoxa-7 coding region provides sufficient regulatory information to specify the anterior boundary of Hoxa-7 gene expression (Püschel et al., 1991). Deletion of $110 \mathrm{bp}$ at the $5^{\prime}$ end of this promoter sequence (position 1944-2054) changed both the expression pattern and frequency considerably, indicating an important regulatory function of this region (Püschel et al., 1991). Furthermore, the high similarity of the human and mouse promoters within this region prompted us to test a series of deletion constructs covering this area.

To identify the minimal control element specifying the anterior boundary of expression, transgenic mice were generated carrying chimeric constructs containing Hoxa-7 promoter sequences fused to a Tk minimal promoter/E. coli lacZ/SV 40 poly A reporter construct. Embryos were dissected at day 12.5 p.c., as at this stage the expression domains of Hoxa-7 are most clearly defined (Dressler and Gruss, 1989; Kessel and Gruss, 1991; Mahon et al., 1988; Püschel et al., 1990; Püschel et al., 1991). Furthermore, the percentage of transgenic and lacZ-expressing embryos was analysed and embryos were classified into low and moderate-to-high expressing groups. The latter distinction of the embryos was performed since an exact definition of the anterior boundary was not possible in low expressing embryos. Therefore embryos displaying only a low level of transgene expression were not used for further analysis.

By deletion analysis of the mouse Hoxa-7 upstream region a 470 bp long fragment (AX 470) specifying an anterior expression boundary from the heterologous Tk promoter was identified that directed expression of the $\beta$-galactosidase protein in a pattern that reflected the anterior boundary of expression of the endogenous Hoxa-7 gene (Fig. 3A, Table 1). In 2 out of 4 embryos expressing the transgene at moderate to high levels a clear anterior boundary was noted at the cervical level. By sectioning the embryos the anterior limit of expression in the neural tube and the spinal ganglia was at level $\mathrm{C} 4$ and $\mathrm{C} 4 / \mathrm{C} 5$ respectively and co-localised with the expression boundary of the endogenous Hoxa-7 gene (Fig. 6A). In particular, the observation that only the caudal half of spinal ganglion $\mathrm{C} 4$ was lacZ-positive and that ganglion $\mathrm{C} 5$ was completely lacZ-positive is a characteristic feature of the anterior boundary of Hoxa-7 (Kessel and Gruss, 1991). 


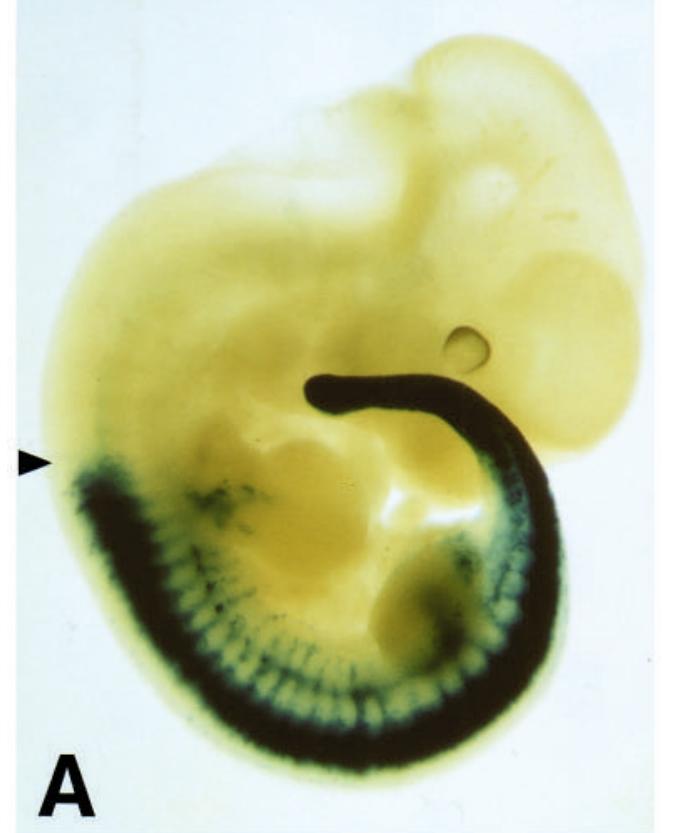

\section{AX 470}$$
1
$$
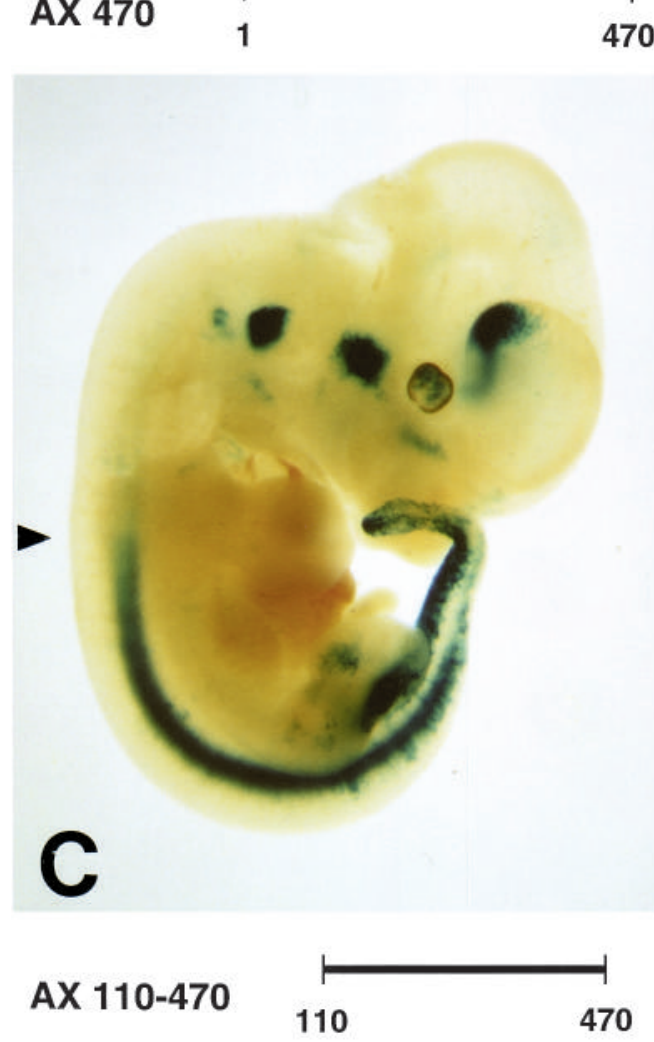
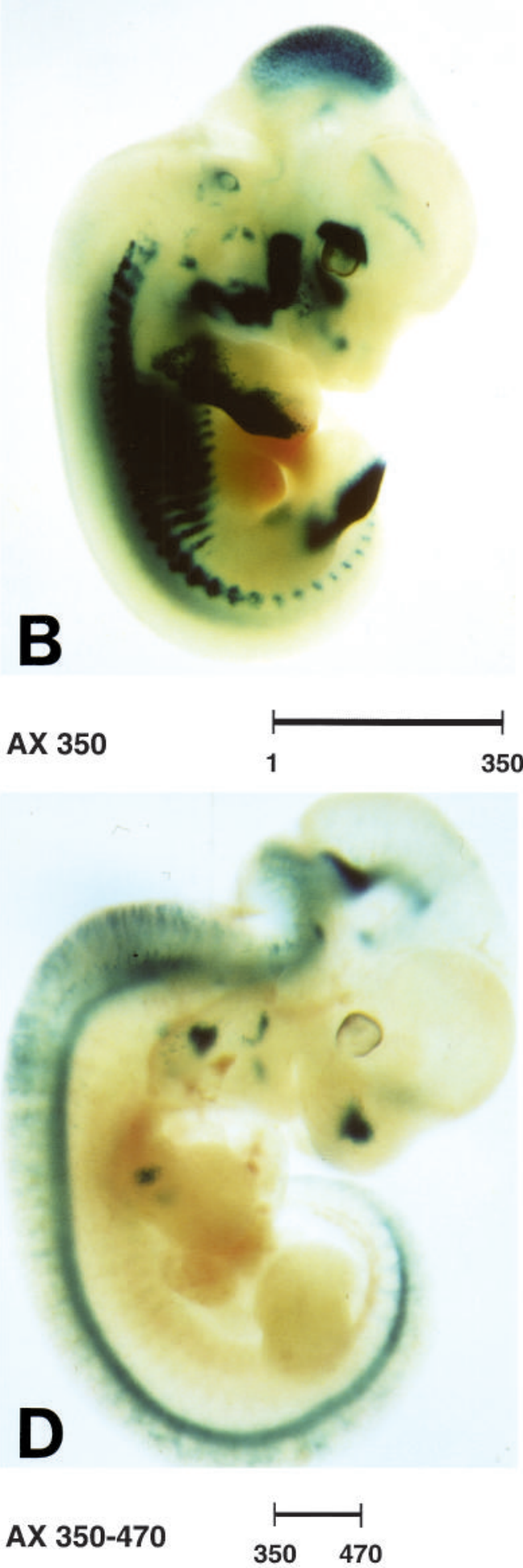

Fig. 3. Identification of a minimal cis-acting element in the upstream region of the Hoxa-7 gene specifying an anterior expression boundary. Sagittal views of whole-mount transgenic embryos expressing Hoxa-7/lacZ hybrid constructs (transient assay). At day 12.5 p.c. embryos were dissected and stained for $\beta$-galactosidase activity. Different Hoxa-7 upstream fragments used to generate transgenics are indicated by length and graphically by the upstream region tested (see also Fig. 1). Embryos carrying AX 470 (A) and AX 350 (B) were classified as high expressing transgenics, embryos with AX 110-470 (C) and AX 350-470 (D) were judged as moderate expressing transgenics. Triangles indicate anterior boundaries of expression (A,C). A Hoxa-7 characteristic anterior boundary of expression was noted only with construct AX 470.
Deletion of $120 \mathrm{bp}$ at the $3^{\prime}$ end of AX 470 fragment generating construct $\mathrm{AX} 350$ resulted in a complete loss of the anterior boundary of Hox gene expression (Fig. 3B, Table 1), which could not be recovered by using the $120 \mathrm{bp}$ at the $3^{\prime}$ end of $\mathrm{AX}$ 470 solely (construct AX 350-470) (Fig. 3D, Table 1). Construct AX 110-470, representing a deletion of $110 \mathrm{bp}$ at the 5 ' end of AX 470, still provided sufficient regulatory information to set up an anterior boundary (Fig. 3C, Table 1).
However, the anterior limit of lacZ expression using AX 110470 promoter sequences was shifted caudally to level C6/C7 (neural tube) and C7/T1 (spinal ganglia) and appeared not to overlap with the Hoxa-7 expression domain. The negative control (construct AX minus carrying no Hoxa-7 promoter sequences) generated only 1 lacZ-positive embryo out of 14 transgenics without any anterior limit of expression. In summary, these experiments identified a 470 bp long minimal 
Table 1. Expression of Hoxa-7 upstream fragments - lacZ fusion genes in transgenic embryos

\begin{tabular}{|c|c|c|c|c|c|c|c|c|}
\hline Construct & $\begin{array}{c}\text { Foster } \\
\text { no. }\end{array}$ & $\begin{array}{c}\text { Embr. } \\
\text { no. }\end{array}$ & $\begin{array}{c}\text { Transgenics } \\
\text { no. }(\%)\end{array}$ & $\begin{array}{c}\text { lacZ+embr. } \\
\text { no. }(\%)\end{array}$ & $\begin{array}{l}\text { Low } \\
\text { expr. }\end{array}$ & $\begin{array}{l}\text { Moderate- } \\
\text { high expr. }\end{array}$ & $\begin{array}{l}\text { Anterior } \\
\text { bound. }\end{array}$ & $\begin{array}{c}\text { Missing } \\
\text { bound. }\end{array}$ \\
\hline AX 470 & 5 & 27 & $12(44)$ & $8(66)$ & 4 & 4 & 2 & 2 \\
\hline AX 350 & 4 & 21 & $10(47)$ & $5(50)$ & 2 & 3 & 0 & 3 \\
\hline AX $110-470$ & 9 & 37 & $10(27)$ & $4(40)$ & 2 & 2 & 2 & 0 \\
\hline AX $350-470$ & 7 & 35 & $16(45)$ & $4(25)$ & 2 & 2 & 0 & 2 \\
\hline AX minus & 6 & 30 & $14(46)$ & $1(7)$ & 0 & 1 & 0 & 1 \\
\hline AX reverse & 4 & 28 & $8(28)$ & $4(50)$ & 0 & 4 & 4 & 0 \\
\hline AX human & 5 & 27 & $14(51)$ & $7(50)$ & 0 & 7 & 6 & 1 \\
\hline
\end{tabular}

Constructs AX 470, AX 350, AX 110-470, AX 350-470, AX minus, AX 470 reverse and AX 500 human were used for injections. Total number of foster mice (foster no.) and of embryos recovered at day 12.5 p.c. (embr. no.) are given. Furthermore, total numbers (no.) and relative percentage (\%) of transgenic embryos identified by PCR (transgenics) and of lacZ-positive embryos (lacZ+embr.) are given. lacZ-positive embryos were classified into low (low expr.) and moderatehigh expressing groups (moderate-high expr.). Embryos expressing lac $Z$ at moderate to high levels were examined for the presence (anterior bound.) or absence (missing bound.) of an anterior expression boundary along the vertebral column.

cis-acting element located at position 1944-2414 of the mouse Hoxa-7 upstream region that provides enough regulatory information to establish the Hoxa-7 expression boundary at day 12.5 p.c.

\section{The cis-acting element functions in reverse orientation}

To study whether element AX 470 is dependent on the Hoxa7 promoter context, AX 470 was cloned in reverse direction in front of the Tk minimal promoter/E. coli lacZ/SV 40 poly A reporter construct and transgenic embryos were analysed at day 12.5 p.c. (Fig. 4A,B) Using 4 foster mice, 28 embryos were recovered, 8 of $28(28 \%)$ were transgenic embryos and 4 of these 8 transgenic embryos gave positive staining reactions for
lacZ. All 4 embryos expressed lac $Z$ at moderate to high levels and showed a distinct anterior boundary mapping to $\mathrm{C} 5 / \mathrm{C} 6$ (neural tube) and $\mathrm{C} 6 / \mathrm{C} 7$ in the case of spinal ganglia (Figs 4, $6 \mathrm{~B})$. Furthermore, expression in vertebrae was noted ranging between $\mathrm{T} 4$ and $\mathrm{T} 8$ depending on the embryo analysed. In one embryo positive staining was detected in the developing kidney, which is known to express Hoxa-7 (Mahon et al., 1988). In all transgenic embryos expressing the AX 470 reverse construct a Hox typical expression pattern with an anterior limit of expression was observed. However, the experimental data might indicate that the anterior boundary specified by element AX 470 in reverse orientation was shifted caudally for 1-2 segments thereby not overlapping with the endogenous Hoxa-7 expression boundary completely.

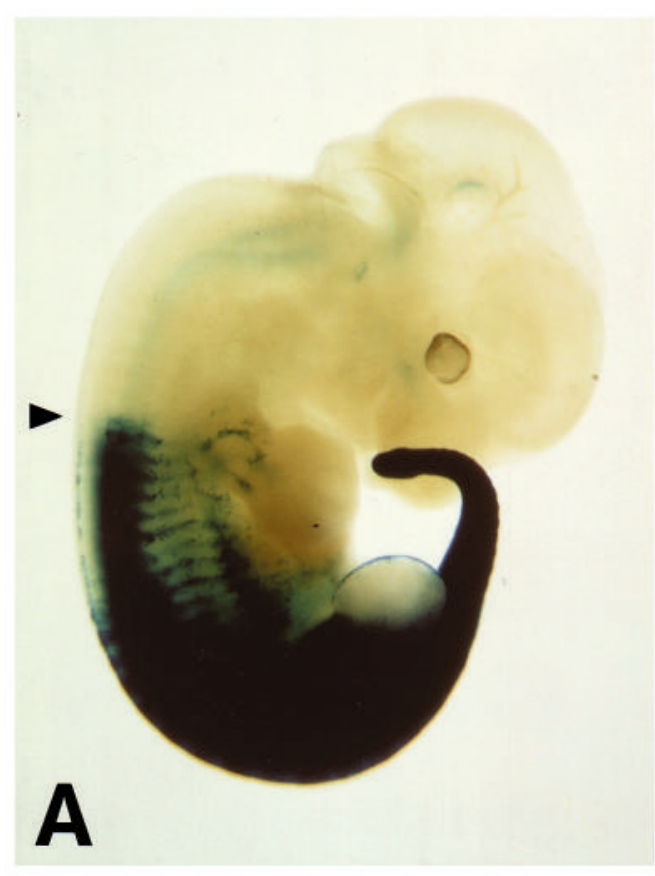

sagittal

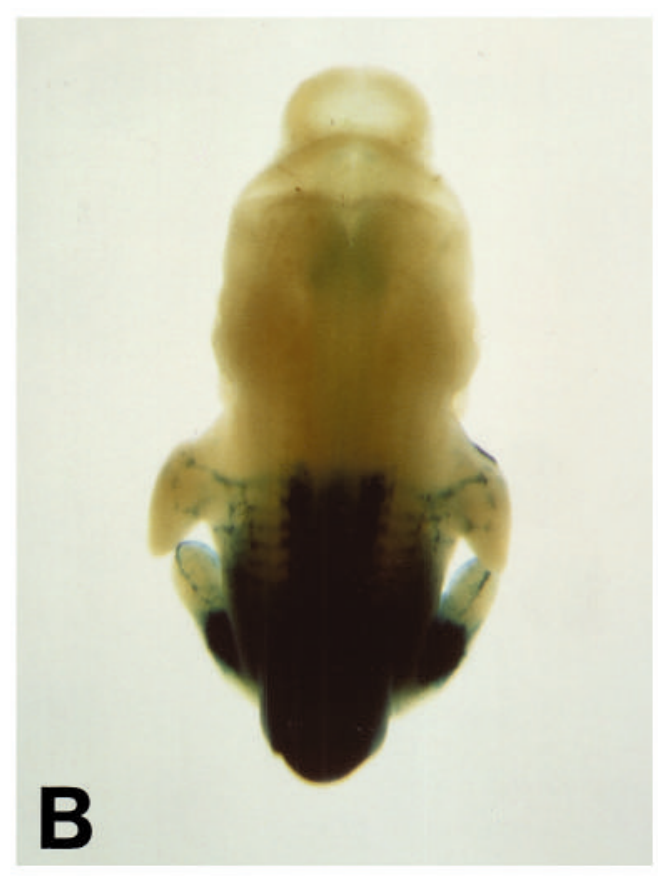

dorsal

\section{AX 470 reverse}

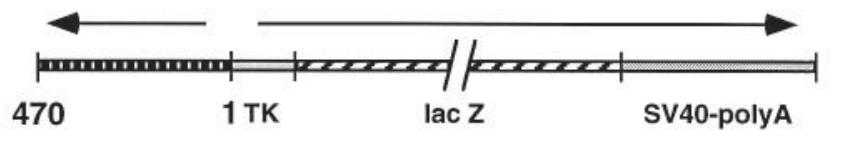

Fig. 4. Analysis of element AX 470 for enhancer activity. Sagittal (A) and dorsal view (B) of a whole-mount transgenic embryo expressing Hox AX 470 reverse/lacZ hybrid constructs (transient assay). At day 12.5 p.c. embryos were dissected and stained for $\beta$-galactosidase activity. Triangle indicates anterior boundary of expression. 


\section{Activity of the human homologue of the mouse Hoxa-7 enhancer}

The mouse and human HOXA7 upstream region are highly conserved through evolution (Fig. 2). Interestingly the AX 470 enhancer element was located within one of these high homology areas. By sequence homology analysis a $502 \mathrm{bp}$ long element within the human $H O X A 7$ promoter was identified which was $76.5 \%$ identical to the mouse AX 470 enhancer (Fig. 5, upper panel). To test whether this element is also func-

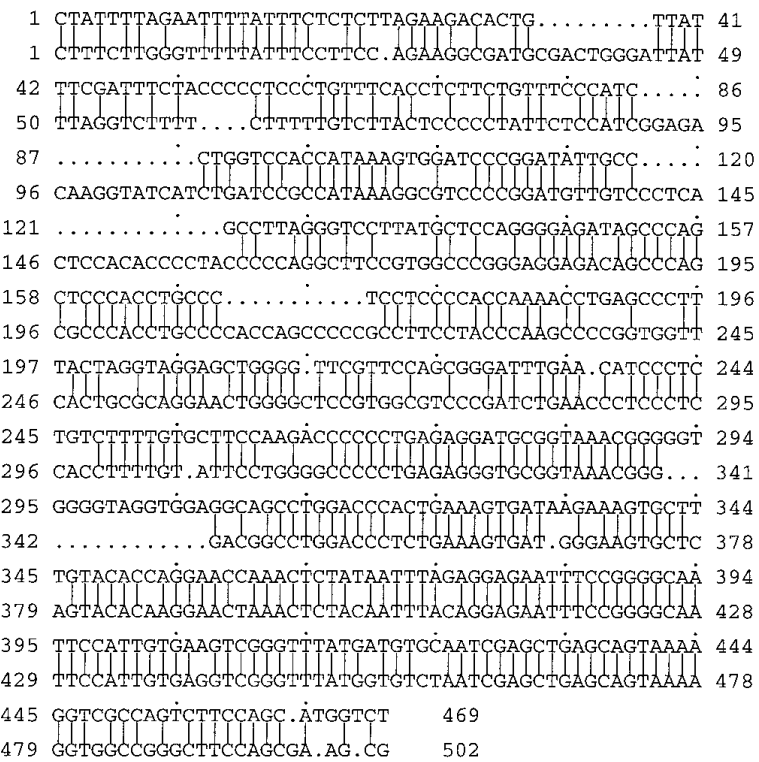

tionally conserved throughout evolution, the human 502 bp long counterpart of the mouse Hoxa-7 enhancer was cloned in front of the reporter construct and transgenic embryos were analysed at day 12.5 p.c. Using 5 foster mice, 27 embryos were recovered, 14 of 27 (51\%) were transgenic and 7 of these 14 embryos gave positive staining for lacZ. All 7 embryos expressed lac $Z$ at moderate to high levels and 6 of 7 embryos showed an anterior boundary (Fig. 5, lower panel). 5 embryos displaying an anterior boundary were further analysed by sectioning (E 1567: strong expression; E 1565, E 1566, E 1568, E 1569: moderate expression). The anterior level of expression in the neural tube was at $\mathrm{C} 5$ in one embryo (E 1567) and at $\mathrm{T} 2$ in 4 embryos (E 1565, E 1566, E 1568, E 1569). The expression boundary in spinal ganglia ranged between C6 (E 1567, Fig. 6C), T5 (E 1568, E 1569) and T7 (E 1565, E 1566). In addition, embryo E 1567 displayed transgene expression in the vertebrae, with an anterior boundary assigned to level T5 and embryo E 1565 showed a lac $Z$ signal in the developing kidney. From the experimental results obtained, the anterior boundary specified by the human AX 500 fragment was not completely identical to that of the endogenous Hoxa-7 gene although in one case (E 1567) the expression limits in spinal ganglia, neural tube and vertebrae were very close to those reported for Hoxa-7. However, in all transgenic embryos expressing the AX 500 human construct a Hox-typical expression pattern and a distinct anterior boundary was observed. We therefore conclude that the human AX 500 sequence represents the homologue of the mouse AX 470 element and that this enhancer element is not only structurally but also functionally conserved through evolution.

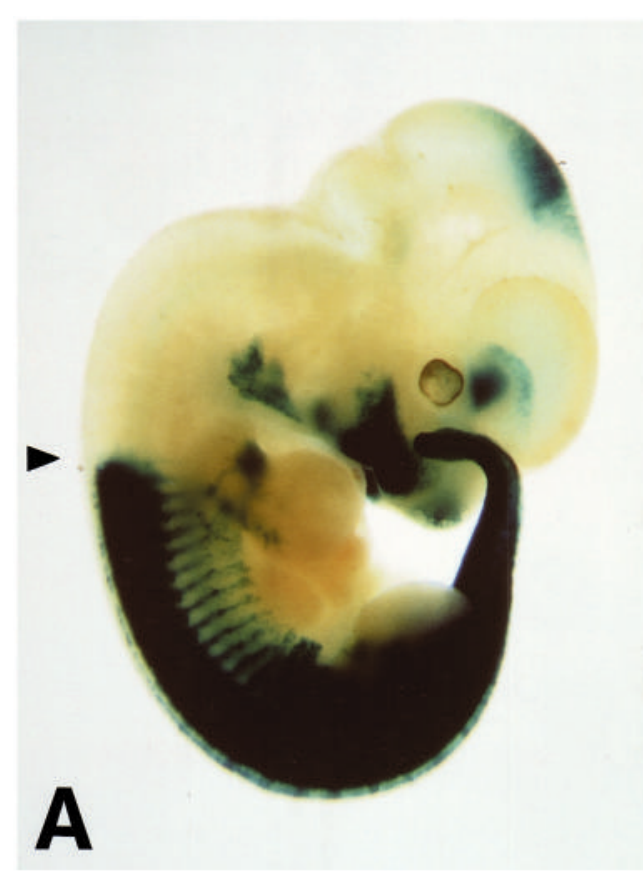

sagittal

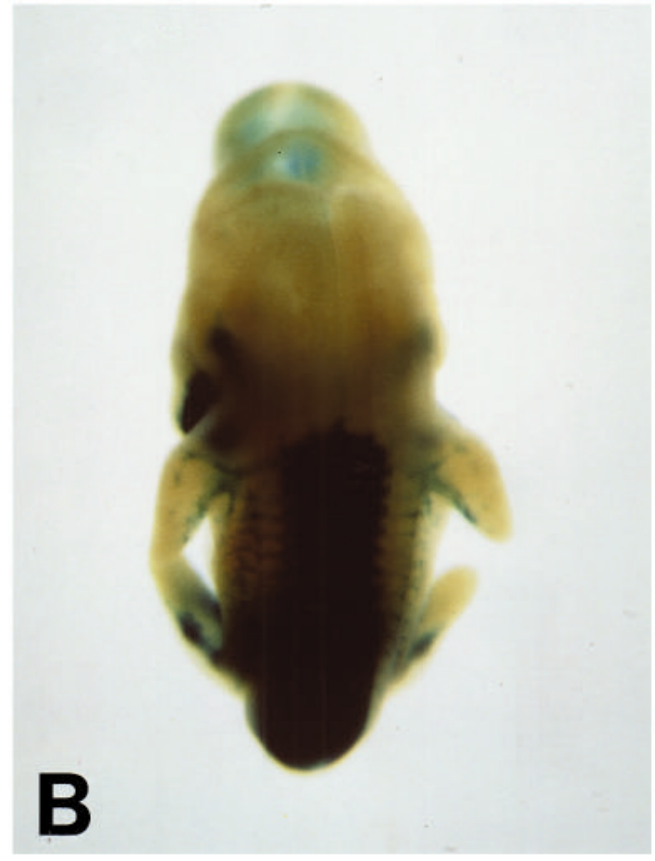

dorsal

\section{AX 500 human}

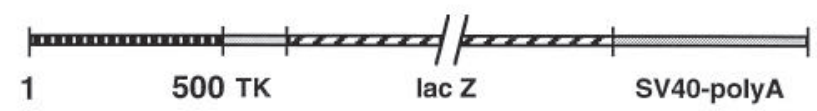

Fig. 5. Structural conservation of the Hoxa-7 enhancer between human and mouse and activity of the human homologue. Upper panel: Sequence comparison of the mouse Hoxa-7 enhancer (upper line, 1-469) and its human homologue (lower line 1-502). Alignment was performed using BestFit from the GCG package, showing $76 \%$ similarity between both sequences (gap weight: 5.0, length weight: 0.1 , average match: 1.0 , average mismatch: $-0.9)$. Lower panel: Activity of the human HOXA7 enhancer in transgenic mice. Sagittal (A) and dorsal view (B) of whole-mount transgenic embryo E 1567 expressing AX 500 human/lacZ hybrid constructs (transient assay). At day 12.5 p.c. embryos were dissected and stained for $\beta$ galactosidase activity. Triangle indicates anterior boundary of expression. 


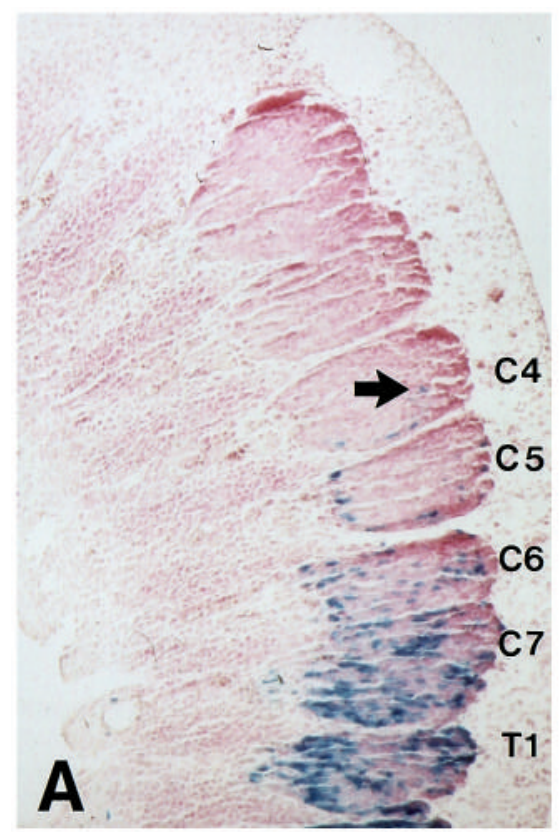

AX 470

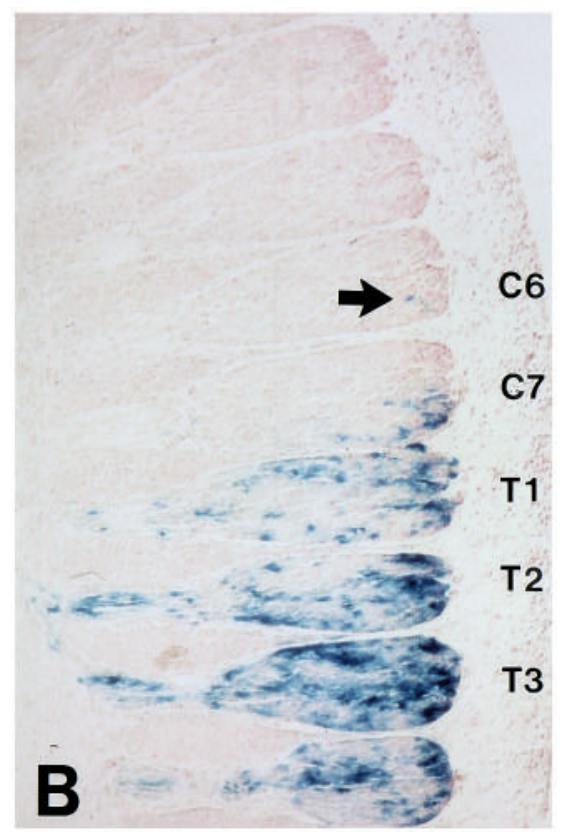

AX 470 reverse

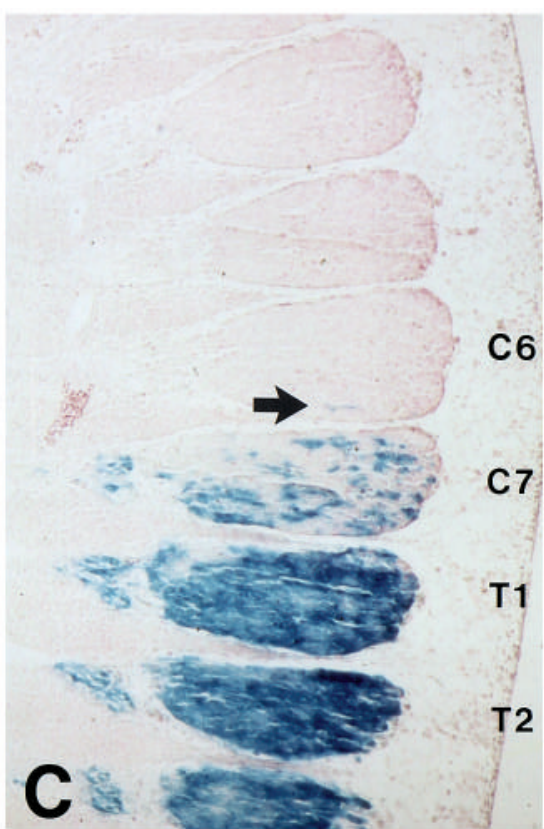

AX 500 human

Fig. 6. Sagittal sections of transgenic embryos expressing Hoxa-7/lacZ hybrid constructs (transient assay). At day 12.5 p.c., embryos were dissected, stained for $\beta$-galactosidase activity and $12-\mu \mathrm{m}$ sections were counterstained with neutral red (see Material and methods). Embryos carrying AX 470 (A) and AX 470 reverse (B) and AX 500 human (C) are shown. Spinal ganglia are numbered consecutively as stated under Methods and the first lacZ-positive ganglion is labeled indicating the anterior boundary of expression. The most anteriorly localized lacZpositive cells demonstrating the anterior limit of transgene expression in spinal ganglia are indicated by arrows. Right is dorsal, left is ventral, rostral is at the top and caudal is at the bottom.

\section{Hoxa-7 enhancer-directed expression during development}

Transgenic lines were generated to allow a detailed analysis of Hoxa-7 enhancer-directed lacZ expression during embryogenesis. In total 5 transgenic founder animals were identified that gave rise to 3 lacZ-expressing mouse lines (L1-L3). The $F_{1}$ generation was analysed in line 1 only, the $F_{2}$ generation was examined in line 1-3.

Hoxa-7 enhancer-directed expression of the lac $Z$ transgene was first detectable at developmental stage 7.5 p.c. in the allantois. At day 8.5, lac Z activity was present in the somites with a distinct anterior boundary at somite 7 (Fig. 7A). Neural crest and especially the neural tube became positive at day 9.5 p.c. A distinct anterior limit of expression was noted in the latter structures, which was located at level $\mathrm{C} 4$ (neural tube) and C5 (spinal ganglia) from day 10.5-13.5 p.c. (Figs 7B-D, $8 \mathrm{~A}-\mathrm{C})$. lacZ staining of the neural tube was present in the ependymal layer, the marginal layer and to a lesser extent in the mantle layer, and showed a dorsal-ventral restriction in that the roof plate was negative in all developmental stages examined (Fig. 8D). Furthermore, transgene activity was observed in paraxial mesoderm (11.5 p.c. onward; Fig. 8E), hindlimb (10.5 p.c. onward), forelimb (11.5 p.c. onward), the developing kidney at day $12.5-13.5$ p.c. (Fig. 8 F), between presumptive ribs and the genital tubercle. In all three lines vertebrae and intervertebral discs were lac $Z$ negative.

Transgene activity was detectable at high levels from day 7.5 until day 12.5 p.c. Starting at day 13.5 p.c. lacZ expression was constantly reduced but was still observable until day 17.5 p.c. Especially at later stages (13.5-17.5 days p.c.) it became evident that an anterior to posterior gradient of transgene activity was present because lac $Z$ staining was more prominent in posterior expression domains compared to its anterior ones (Fig. 7).

A distinct anterior expression boundary was observable in line 2-3 throughout development and inconsistently in line 1. In early stages of development (7.5-9.5 days p.c.) L1 embryos showed expression patterns identical to L2 and L3. In contrast, at later stages (10.5-13.5 p.c.) the anterior boundary in L1 embryos was shifted rostrally to the midbrain-hindbrain boundary. This effect was observed in the majority of L1 embryos, however, a small number of L1 embryos still showed the Hoxa-7 characteristic level of expression at these stages. This anterior shift seemed to occur more often in the $F_{2}$ than in the $F_{1}$ generation. In about $87 \%$ of the embryos of the $F_{1}$ generation and in about $94 \%$ of the $\mathrm{F}_{2}$ generation embryos this shift was observed.

\section{DISCUSSION}

The molecular analysis of regulatory elements defining the onset of Hox gene expression in time and space is of crucial importance for the understanding of the developmental programme specifying positional information. In the case of Hoxa-7, previous studies have defined separate elements specifying expression boundaries and lineage restriction, which are required at different stages of development (Püschel et al., 
1990, 1991). The aim of the present study was the identification of the minimal regulatory element specifying the anterior boundary of Hoxa-7 expression. Using the transgenic mouse model and a series of deletions of the Hoxa-7 upstream region, a $470 \mathrm{bp}$ long fragment was identified that directed expression of the $\beta$-galactosidase protein in a pattern that reflected the expression pattern of the endogenous Hoxa-7 gene in space and time. Further $5^{\prime}$ and $3^{\prime}$ deletions of this element resulted in a loss of the specific expression pattern, demonstrating that this $470 \mathrm{bp}$ long upstream region was the minimal control element. In transient assays and in 3 transgenic lines the 470 bp long fragment was sufficient to specify the correct anterior boundary of Hox gene expression and a ventraldorsal restriction in the spinal cord. The onset and the time course of transgene expression during development were in perfect agreement with published data about the temporal regulation of the endogenous Hoxa-7 gene (Dressler and Gruss, 1989; Mahon et al., 1988). Furthermore, the element had enough regulatory information to restrict expression of the transgene to predicted tissues (e.g. spinal ganglia, neural tube) which express the endogenous Hoxa-7 gene. However, as expected from earlier work (Püschel et al., 1990, 1991) the endogenous Hoxa-7 expression was not fully reproduced by this element. In particular a posterior expression boundary was missing and some embryonic structures positive for endogenous Hoxa-7, e.g. vertebrae, intervertebral disc anlagen, kidney, lung and stomach, were inconsistently positive or even negative. Cloning the 470 bp long fragment in opposite direction in front of an unrelated promoter demonstrated that the element was active in

AX 470 either direction. Based on these results the $470 \mathrm{bp}$ long element (AX 470) was designated as Hoxa-7 enhancer.

There is growing evidence that potential regulatory elements

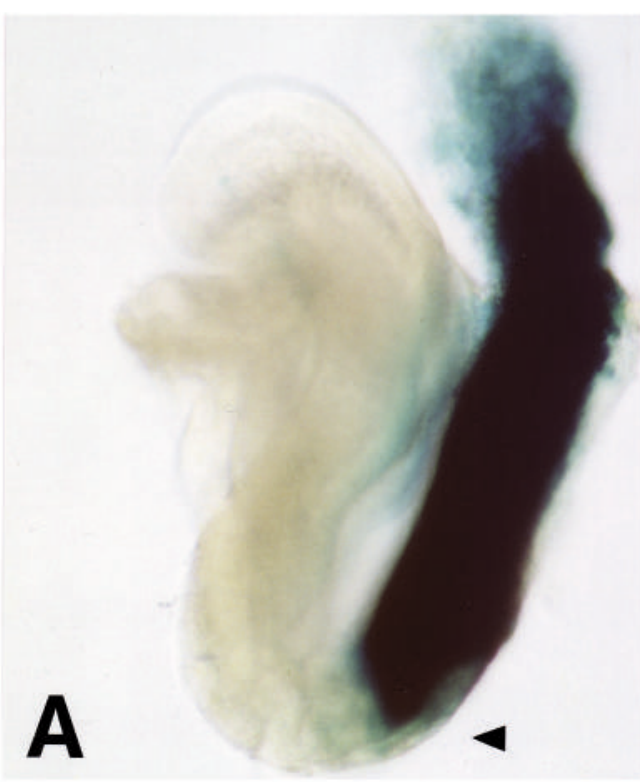

day 8,5 p.c.

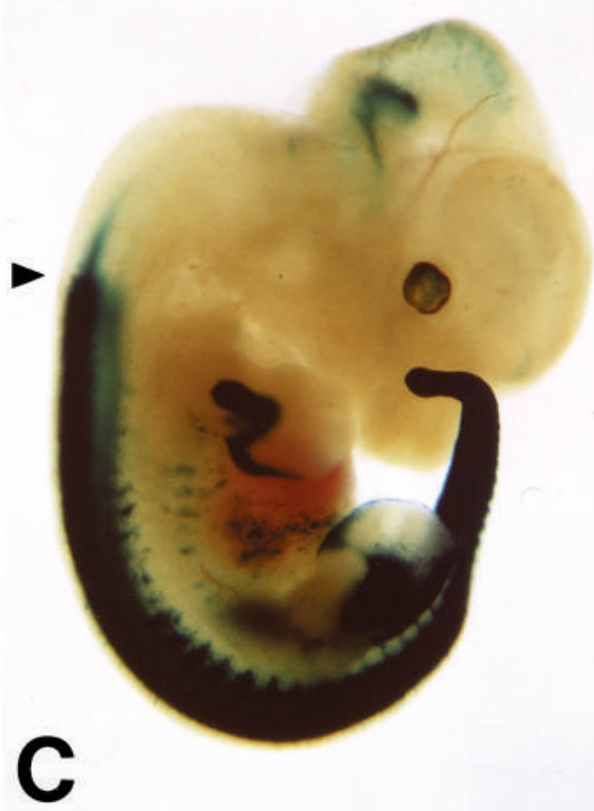

day 12,5 p.c.

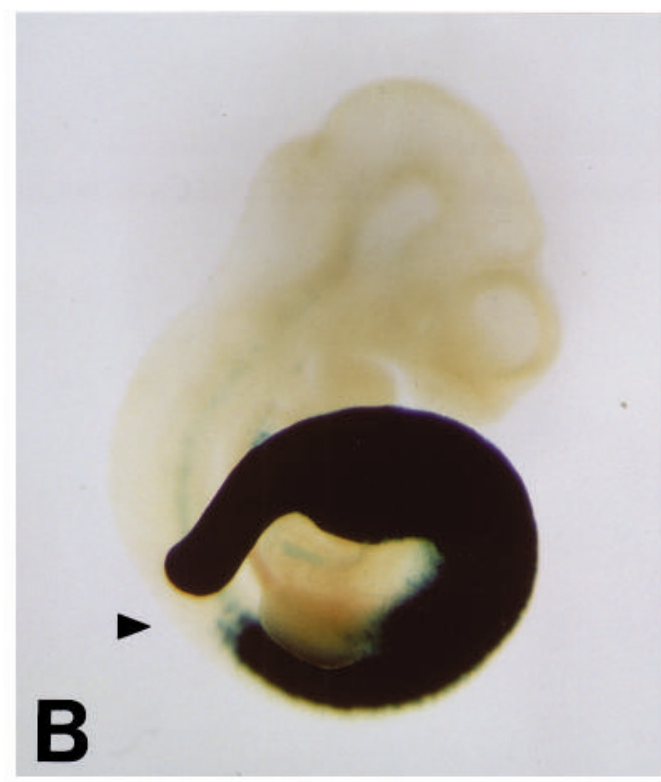

day 10,5 p.c.

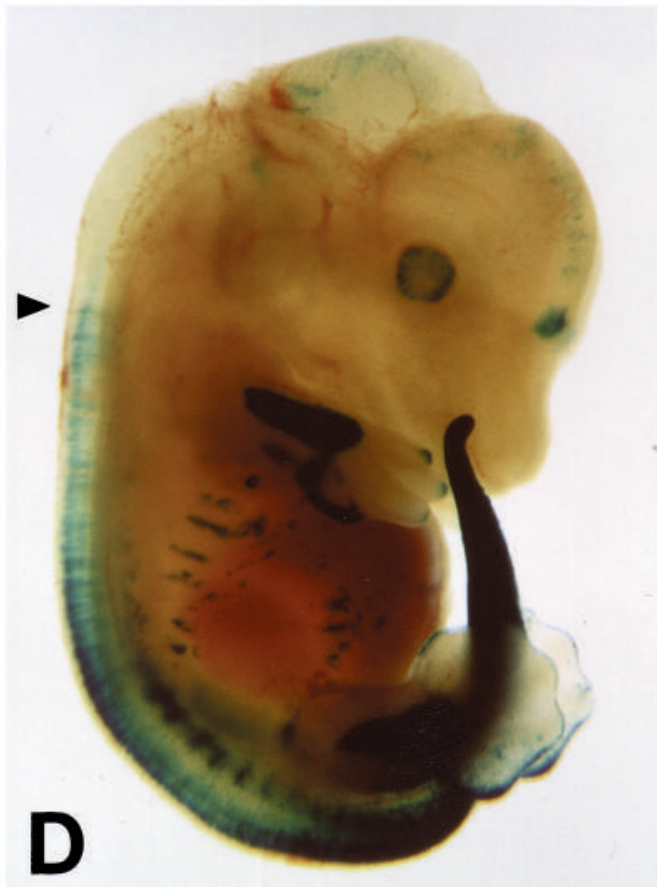

day 13,5 p.c.

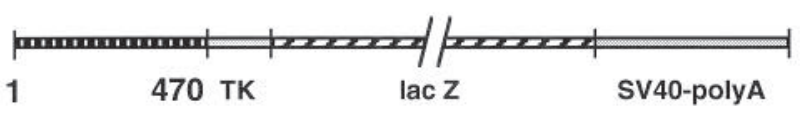

Fig. 7. Expression patterns of Hoxa-7 enhancer/lacZ hybrid genes in transgenic lines during development. Transgenic lines were established using Hox AX 470 fragment fused to a Tk minimal promoter/E. coli lacZ/SV 40 poly A reporter construct and embryos at days 6.5-17.5 p.c. were dissected and stained for $\beta$-galactosidase activity. Sagittal views of whole-mount embryos of line 2 at days 8.5 (A), 10.5 (B), 12.5 (C) and 13.5 p.c (D) are shown. Triangles indicate anterior boundaries of expression. 

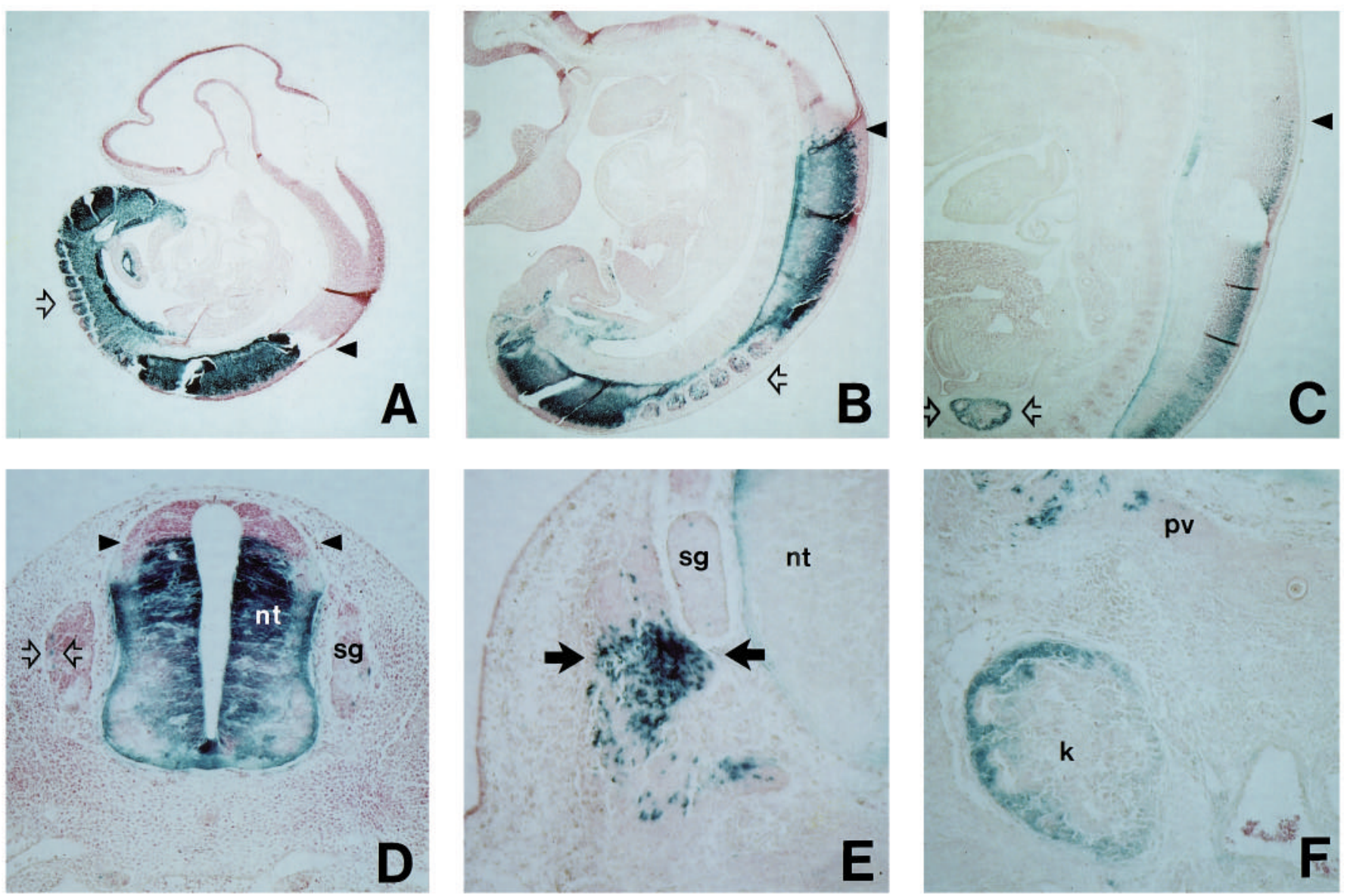

Fig. 8. Sections of transgenic embryos of line 2 at days 10.5-12.5 p.c. At day 10.5 (A), 11.5 (B, D) and 12.5 p.c. (C, E, F) embryos were dissected, stained for $\beta$-galactosidase activity and $12-\mu \mathrm{m}$ sections were counterstained with neutral red (see Material and methods). Sagittal (AC) and axial (D-F) sections are shown. (A-C) Right is dorsal, left is ventral, rostral is at the top and caudal is at the bottom. The anterior boundary of transgene expression in the neural tube is illustrated by triangles. In A and B open arrows show spinal ganglia. In $\mathrm{C}$ an open arrow marks the developing kidney. (D-F) Dorsal is at the top and ventral is at the bottom. (D) Triangles show the dorsal-ventral restriction of expression, note the negative roof plate. Open arrows indicate lacZ-positive cells in the spinal ganglia. (E) lacZ-positive cells are detected in the paraxial mesoderm (arrows). (F) Transgene expression in the developing kidney. Abbreviations: sg, spinal ganglia; nt, neural tube; pv, prevertebrae; $\mathrm{k}$, kidney.

of Hox genes are conserved throughout evolution. Conserved sequences of $H O X D 9, D 11, B 5, B 6$ and $C 5$ genes were defined between species in non-coding areas (Ericson et al., 1993; Gerard et al., 1993; Molven et al., 1993; Renucci et al., 1992) suggesting an identical mechanism of regulation. In the present study, $3.6 \mathrm{~kb}$ of the mouse and $3.0 \mathrm{~kb}$ of the human Hoxa-7 upstream region were sequenced and compared by general alignment programs. The human and murine Hoxa-7 upstream gene structure were strikingly conserved in distinct areas while other promoter regions diverged considerably. Interestingly, the Hoxa-7 enhancer mapped to one of these high homology regions. Furthermore, the enhancer element was not only structurally but also functionally conserved since the human HOXA7 homologue was able to set an anterior boundary of expression in transgenic mice. These data confirm previous observations showing that Hox regulatory elements are active when tested in other species (Westerfield et al., 1992) and strengthens the hypothesis that the mechanism controlling Hox gene expression is conserved between species.

Although the spatial, temporal and tissue-specific expression patterns of Hox genes have been thoroughly described, little is known about the establishment of these expression patterns. In order to study the regulation of Hox gene expression, in vitro and in vivo test systems are used. For in vitro analysis potential regulatory sequences are analysed mostly in DNA binding assays or in cell transfection experiments using reporter genes under the control of Hox sequences. It has been shown that in the non-coding regions of Hox genes sequence motifs are present which bind to nuclear protein extracts prepared from tissue culture cells or embryos and to retinoic acid inducible factors (Arcioni et al., 1992; Coletta et al., 1991). More detailed studies demonstrated that Hox promoter sequences contain retinoic acid response elements or bind retinoic acid receptors (Marshall et al., 1994; Moroni et al., 1993; Popperl and Featherstone, 1993; Studer et al., 1994) and interact with Hox proteins and transcription factors like Krox-20 and USF (Chavrier et al., 1990; Galang and Hauser, 1992; Wu and Wolgemuth, 1993; Zappavigna et al., 1991; Zwartkruis et al., 1991). One sequence that is frequently found in homeodomain binding sites present in the non-coding areas contains a core 
ATTA motif within a larger consensus sequence. Recently regulatory proteins that are highly related to activators or repressors of homeotic gene expression in Drosophila, were identified in mammals too. Brgl represents the putative murine homologue of the Drosophila brahma gene and is detected within the spinal cord and vertebral column encompassing major regions of Hox gene expression (Randazzo et al., 1994). However, although a precise definition of positive and negative regulatory elements and putative transcription factors has been reported, definitive proof of their functional significance awaits an in vivo analysis.

To localise cis regulatory Hox sequences in vivo, transgenic mice carrying the $l a c Z$ gene under the control of regulatory Hox elements are widely used. Hox genomic sequences reproduced major aspects of individual Hox gene expression patterns and demonstrated that the genomic localisation of the transgene within the Hox cluster was not required for proper regulation. Initially, sequences tested for regulatory potential were relatively large and a fine mapping of distinct regulatory elements was not possible. Further studies demonstrated the presence of multiple negatively and positively acting elements (Gerard et al., 1993). It also became evident that control elements are required at different stages of development suggesting a biphasic mechanism of Hox gene expression. Elements responsible for correct initiation of Hox gene expression and elements controlling its proper maintenance have been described (Bieberich et al., 1990; Gerard et al., 1993). Besides the correct temporal and spatial distribution, sequences have been defined which control particular aspects of Hox expression e.g. HOXB4 expression in the neural tube (Whiting et al., 1991) or Hoxa-7 expression in vertebrae (Püschel et al., 1991). Furthermore, a regionspecific enhancer in the $5^{\prime}$ flanking sequence of the HOXA5 gene has been identified that might activate transcription from the HOXA5 proximal promoter within specific CNS domains (Tuggle et al., 1990). In addition, it has been proposed that regulatory elements might act over large distances influencing the expression of more than one gene in the cluster (Sham et al., 1992). In a first step in elucidating the role of transcription factors in vivo it has been demonstrated that the zinc finger protein Krox20 is part of the upstream transcriptional cascade that directly regulates $H O X B 2$ expression during hindbrain segmentation via binding to an upstream enhancer element (Sham et al., 1993). Recently, it has been demonstrated in vivo that retinoids and their nuclear receptors are involved in the regulation of the segment restricted expression pattern of Hoxb-1 during rhombomere boundary formation (Marshall et al., 1994; Studer et al., 1994). In summary, a complex cooperation between regulatory units and transcription factors seems to control Hox gene expression in time and space.

In mouse, rather large elements responsible for the specification of the anterior boundary of expression have been mapped for the Hoxa-7, Hoxb-4, Hoxc-6 and Hoxc-8 genes (Behringer et al., 1993; Bieberich et al., 1990; Jegalian et al., 1992; Püschel et al., 1990, 1991; Whiting et al., 1991). A more recent study provided evidence for at least three cis-acting control elements upstream from Hoxb-7 and for cooperative interactions between some of these elements in generating the A-P restricted transgenic pattern (Vogels et al., 1993). In particular a 450 bp long DNA fragment located in the trailer of the $H o x b-8$ gene mediated regionally restricted expression when acting together with a functional Hoxb-7 promoter.

The data presented in this study identify a minimal enhancer element specifying the anterior boundary of Hox gene expression. Furthermore this enhancer element also had enough regulatory information to express the transgene at the appropriate time in the correct tissues of the embryo. Since the Hoxa-7 enhancer is located about $1.6 \mathrm{~kb}$ upstream of the Hoxa7 coding sequence we speculate that this remote control element might cooperate with proximal elements thereby directing Hoxa-7 gene expression. However, it is also possible that the regulatory unit acts independently from the proximal Hoxa-7 promoter region and influences the expression of other Hox genes located in close proximity suggesting that the expression of adjactent Hox genes is controlled by common regulatory units. This idea is supported by our observation that in transgenic embryos carrying the enhancer element placed in opposite direction (AX 470 reverse) the anterior boundary might be shifted caudally by about $1-2$ segments. The latter expression limit could represent the presently unknown anterior boundary of Hoxa-8, which is located directly upstream of Hoxa-7.

Although the Hoxa-7 enhancer did not fully reproduce the endogenous Hoxa-7 expression pattern the definition of this element specifying positional information in time and space should provide a powerful tool to study the molecular basis of positional signalling during embryogenesis.

We thank E. Boncinelli for providing the human HOXA7 clone carrying the HOXA7 upstream sequence, U. Franke for excellent technical assistance and H.P. Geithe for the synthesis of oligonucleotides and automatic sequencing. We are also indebted to R. Altschäffel for the photographic work. Finally we would like to thank E. Stuart and M. Gross for helpful discussions and critical comments on the manuscript. T. K. was supported by the Deutsche Forschungsgemeinschaft (grant Kn 328/1-1).

\section{REFERENCES}

Akam, M., Dawson, I. and Tear, G. (1988). Homeotic genes and the control of segment diversity. Development 104 Supplement, 123-133.

Arcioni, L., Simeone, A., Guazzi, S., Zappavigna, V., Boncinelli, E. and Mavilio, F. (1992). The upstream region of the human homeobox gene $\mathrm{HOX} 3 \mathrm{D}$ is a target for regulation by retinoic acid and HOX homeoproteins. EMBO J. 11, 265-277.

Balling, R., Mutter, G., Gruss, P. and Kessel, M. (1989). Craniofacial abnormalities induced by ectopic expression of the homeobox gene Hox-1.1 in transgenic mice. Cell 58, 337-347.

Behringer, R. R., Crotty, D. A., Tennyson, V. M., Brinster, R. L., Palmiter, R. D. and Wolgemuth, D. J. (1993). Sequences $5^{\prime}$ of the homeobox of the Hox-1.4 gene direct tissue-specific expression of lac $Z$ during mouse development. Development 117, 823-833.

Bieberich, C. J., Utset, M. F., Awgulewitsch, A. and Ruddle, F. H. (1990). Evidence for positive and negative regulation of the Hox-3.1 gene. Proc. Natl. Acad. Sci. USA 87, 8462-8466.

Chavrier, P., Vesque, C., Galliot, B., Vigneron, M., Dolle, P., Duboule, D. and Charnay, P. (1990). The segment-specific gene Krox-20 encodes a transcription factor with binding sites in the promoter region of the Hox-1.4 gene. EMBO J. 9, 1209-1218.

Chisaka, O. and Capecchi, M. R. (1991). Regionally restricted developmental defects resulting from targeted disruption of the mouse homeobox gene Hox1.5. Nature 350, 473-479.

Chisaka, O., Musci, T. S. and Capecchi, M. R. (1992). Developmental defects of the ear, cranial nerves and hindbrain resulting from targeted disruption of the mouse homeobox gene Hox-1.6. Nature 355, 516-520. 
Coletta, P. L., Shimeld, S. M., Chaudhuri, C., Muller, U., Clarke, J. P. and Sharpe, P. T. (1991). Characterisation of the murine Hox-3.3 gene and its promoter. Mech. Dev. 35, 129-142.

Dressler, G. R. and Gruss, P. (1989). Anterior boundaries of Hox gene expression in mesoderm-derived structures correlate with the linear gene order along the chromosome. Differentiation 41, 193-201.

Ericson, J. U., Krauss, S. and Fjose, A. (1993). Genomic sequence and embryonic expression of the zebrafish homeobox gene hox-3.4. Int. J. Dev. Biol. 37, 263-272.

Galang, C. K. and Hauser, C. A. (1992). Cooperative DNA binding of the highly conserved human Hox 2.1 homeodomain gene product. New Biol. 4, 558-568.

Gerard, M., Duboule, D. and Zakany, J. (1993). Structure and activity of regulatory elements involved in the activation of the Hoxd-11 gene during late gastrulation. EMBO J. 12, 3539-3550.

Guthrie, S., Muchamore, I., Kuroiwa, A., Marshall, H., Krumlauf, R. and Lumsden, A. (1992). Neuroectodermal autonomy of Hox-2.9 expression revealed by rhombomere transpositions. Nature 356, 157-159.

Hogan, B., Constantini, F. and Lacy, E. (1986). Manipulating the Mouse Embryo. Cold Spring Harbor, New York: Cold Spring Harbor Laboratory Press.

Hunt, P., Whiting, J., Nonchev, S., Sham, M. H., Marshall, H., Graham, A., Cook, M., Allemann, R., Rigby, P. W., Gulisano, M., Faiella, A., Boncinelli, E. and Krumlauf, R. (1991). The branchial Hox code and its implications for gene regulation, patterning of the nervous system and head evolution. Development Supplement 2, 63-77.

Jegalian, B. G., Miller, R. W., Wright, C. V. E., Blum, M. and De Robertis, E. M. (1992). A Hox 3.3-lacZ transgene expressed in developing limbs. Mech. Dev. 39, 171-180.

Kappa, C., Schughart, K. and Ruddle, F. H. (1993). Early evolutionary origin of major homeodomain sequence classes. Genomics 18, 54-70.

Kessel, M. (1992). Respecification of vertebral identities by retinoic acid. Development 115, 487-501.

Kessel, M. (1993). Reversal of axonal pathways from rhombomere 3 correlates with extra Hox expression domains. Neuron 10, 379-93.

Kessel, M., Balling, R. and Gruss, P. (1990). Variations of cervical vertebrae after expression of a Hox-1.1 transgene in mice. Cell 61, 301-8.

Kessel, M. and Gruss, P. (1990). Murine developmental control genes. Science 249, 374-379.

Kessel, M. and Gruss, P. (1991). Homeotic transformations of murine vertebrae and concomitant alteration of Hox codes induced by retinoic acid. Cell 67, 89-104.

Kress, C., Vogels, R., De, G. W., Bonnerot, C., Meijlink, F., Nicolas, J. F. and Deschamps, J. (1990). Hox-2.3 upstream sequences mediate lac $Z$ expression in intermediate mesoderm derivatives of transgenic mice. Development 109, 775-786.

Lufkin, T., Dierich, A., LeMeur, M., Mark, M. and Chambon, P. (1991). Disruption of the Hox-1.6 homeobox gene results in defects in a region corresponding to its rostral domain of expression. Cell 66, 1105-1119.

Lufkin, T., Mark, M., Hart, C. P., Dolle, P., LeMeur, M. and Chambon, P. (1992). Homeotic transformation of the occipital bones of the skull by ectopic expression of a homeobox gene. Nature 359, 835-841.

Mahon, K. A., Westphal, H. and Gruss, P. (1988). Expression of homeobox gene Hox 1.1 during mouse embryogenesis. Development 104 Supplement, 187-195.

Maniatis, M., Fritsch, E. F. and Sambrokk, J. (1982). Molecular Cloning. A Laboratory Manual. Cold Spring Harbor, New York: Cold Spring Harbor Laboratory Press.

Marshall, H., Studer, M., Pöpperl, H., Aparicio, S., Kuroiwa, A., Brenner, S. and Krumlauf, R. (1994). A retinoic acid response element required for early expression of the homeobox gene Hoxb-1. Nature 370, 567-571.

McGinnis, W. and Krumlauf, R. (1992). Homeobox genes and axial patterning. Cell 68, 283-302.

Molven, A., Hordvik, I. and Njolstad, P. R. (1993). Sequence analysis of the zebrafish hox-B5/B6 region. Biochim. Biophys. Acta 1173, 102-106.

Morgan, B. A., Izpisua, B. J., Duboule, D. and Tabin, C. J. (1992). Targeted misexpression of Hox-4.6 in the avian limb bud causes apparent homeotic transformations. Nature 358, 236-239.

Moroni, M. C., Vigano, M. A. and Mavilio, F. (1993). Regulation of the human HOXD4 gene by retinoids. Mech. Dev. 44, 139-154.
Popperl, H. and Featherstone, M. S. (1993). Identification of a retinoic acid response element upstream of the murine Hox-4.2 gene. Mol. Cell. Biol. 13, 257-265.

Püschel, A. W., Balling, R. and Gruss, P. (1990). Position-specific activity of the Hox1.1 promoter in transgenic mice. Development 108, 435-442.

Püschel, A. W., Balling, R. and Gruss, P. (1991). Separate elements cause lineage restriction and specify boundaries of Hox-1.1 expression. Development 112, 279-287.

Püschel, A. W., Gruss, P. and Westerfield, M. (1992). Sequence and expression pattern of pax-6 are highly conserved between zebrafish and mice. Development 114, 643-651.

Randazzo, F. M., Khavari, P., Crabtree, G., Tamkun, J. and Rossant, J. (1994). brg1: a putative murine homologue of the Drosophila brahma gene, a homeotic gene regulator. Dev. Biol. 161, 229-242.

Renucci, A., Zappavigna, V., Zakany, J., Izpisua, B. J. C., Burki, K. and Duboule, D. (1992). Comparison of mouse and human HOX-4 complexes defines conserved sequences involved in the regulation of Hox-4.4. EMBO J. 11, 1459-1468.

Scholer, H. R., Balling, R., Hatzopoulus, K., Suzuki, N. and Gruss, P. (1989). Octamer binding proteins confer transcriptional activity in early mouse embryogenesis. Embo J 8, 2551-2557.

Schubert, F. R., Nieselt-Struwe, K. and Gruss, P. (1993). The Antennapediatype homeobox genes have evolved from three precursors separated early in metazoan evolution. Proc. Natl. Acad. Sci. USA 90, 143-147.

Schughart, K., Bieberich, C. J., Eid, R. and Ruddle, F. H. (1991). A regulatory region from the mouse Hox-2.2 promoter directs gene expression into developing limbs. Development 112, 807-811.

Sham, M. H., Hunt, P., Nonchev, S., Papalopulu, N., Graham, A., Boncinelli, E. and Krumlauf, R. (1992). Analysis of the murine Hox-2.7 gene: conserved alternative transcripts with differential distributions in the nervous system and the potential for shared regulatory regions. EMBO J. 11, 1825-36.

Sham, M. H., Vesque, C., Nonchev, S., Marshall, H., Frain, M., Gupta, R. D., Whiting, J., Wilkinson, D., Charnay, P. and Krumlauf, R. (1993). The zinc finger gene Krox20 regulates HoxB2 (Hox2.8) during hindbrain segmentation. Cell 72, 183-196.

Studer, M., Pöpperl, H., Marshall, H., Kuroiwa, A. and Krumlauf, R. (1994). Role of a conserved retinoic acid response element in rhombomere restriction of Hoxb-1. Science 265, 1728-1732.

Theiler, K. (1972). The House Mouse. Development and Normal Stages from Fertilization to 4 Weeks of Age. New York: Springer Verlag.

Tuggle, C. K., Zakany, J., Cianetti, L., Peschle, C. and Nguyen, H. M. C. (1990). Region-specific enhancers near two mammalian homeo box genes define adjacent rostrocaudal domains in the central nervous system. Genes Dev. 4, 180-189.

Vogels, R., Charite, J., de, G. W. and Deschamps, J. (1993). Proximal cisacting elements cooperate to set Hoxb-7 (Hox-2.3) expression boundaries in transgenic mice. Development 118, 71-82.

Westerfield, M., Wegner, J., Jegalian, B. G., DeRobertis, E. M. and Püschel, A. W. (1992). Specific activation of mammalian Hox promoters in mosaic transgenic zebrafish. Genes Dev. 6, 591-598.

Whiting, J., Marshall, H., Cook, M., Krumlauf, R., Rigby, P. W., Stott, D. and Allemann, R. K. (1991). Multiple spatially specific enhancers are required to reconstruct the pattern of Hox-2.6 gene expression. Genes Dev. $\mathbf{5}$, 2048-2059.

Wu, K. and Wolgemuth, D. J. (1993). Protein product of the somatic-type transcript of the Hoxa-4 (Hox-1.4) gene binds to homeobox consensus binding sites in its promoter and intron. J. Cell Biochem. 52, 449-462.

Zakany, J., Tuggle, C. K., Patel, M. D. and Nguyen, H. M. C. (1988). Spatial regulation of homeobox gene fusions in the embryonic central nervous system of transgenic mice. Neuron 1, 679-691.

Zappavigna, V., Renucci, A., Izpisua, B. J. C., Urier, G., Peschle, C. and Duboule, D. (1991). HOX4 genes encode transcription factors with potential auto- and cross-regulatory capacities. EMBO J. 10, 4177-4187.

Zwartkruis, F., Hoeijmakers, T., Deschamps, J. and Meijlink, F. (1991). Characterization of the murine Hox-2.3 promoter: involvement of the transcription factor USF (MLTF). Mech. Dev. 33, 179-190.

(Accepted 20 December 1994) 